\title{
Effects of postoperative intravenous infusion of tramadol and addition of dexmedetomidine to tramadol on analgesia and hemodynamic parameters in gynecologic surgery: a prospective (double blind) randomised controlled trial
}

\author{
Jinekolojik cerrahide postoperatif uygulanan intravenöz tramadolün ve tramadole deksmedetomidin ilavesinin \\ analjezi ve hemodinamik parametreler üzerine etkileri: Prospektif (çift kör) randomize kontrollü çalışma
}

Hakan Emirkadı ${ }^{1}$, Hüseyin Şen ${ }^{1}$, Güner Dağlı ${ }^{2}$, Bulat Aytek Şık ${ }^{3}$, Yaşam Kemal Akpak ${ }^{4}$

\begin{abstract}
Aim: We designed this double-blind study to test and compare the effects of intravenous tramadol and intravenous tramadol plus dexmedetomidine on analgesia and hemodynamic parameters for treatment of postoperative pain in gynecologic surgeries with Pfannenstiel incision.

Methods: Sixty patients undergoing total abdominal hysterectomy with Pfannenstiel incision under genera anesthesia were randomly allocated into two groups. Group C (Tramadol) and Group D (Tramadol + Dexmedetomidin). The anesthetic technique was standardized. Postoperatively, the patients in both groups received patient controlled analgesia during 24 hours after surgery (tramadol $20 \mathrm{mg}$ bolus for Group C, tramado $20 \mathrm{mg}+$ dexmedetomidine $10 \mathrm{mg}$ first four hours, then tramadol $20 \mathrm{mg}$ for Group D with a lock-out time of 15 minutes). Postoperative assessment included verbal pain score, sedation score, nausea and vomiting score, consumption of tramadol, hemodynamic parameters and patient's satisfaction.

Results: Postoperative pain scores were significantly lower in Group D compared with Group C and patient controlled analgesia tramadol use was significantly reduced in Group D. Total PCA tramadol use was decreased by $27 \%$ in Group D compared with Group C $(\mathrm{p}=0.001)$. Patient satisfaction with pain treatment was significantly improved in Group D compared with Group $\mathrm{C}(\mathrm{p}=0.001)$. A significant increase in sedation scores at the 1st, 2nd and 4th hours were observed in Group D. Heart rate was lower in Group D at the 1st, 2nd and 4th hours postoperatively $(\mathrm{p}=0.001, \mathrm{p}=0.001$ and $\mathrm{p}=0.01$, respectively). Nausea and vomiting score was lower in Group D ( $\mathrm{p}<0.05$ for all).

Conclusion: The addition of dexmedetomidine to tramadol by patient controlled analgesia method significantly reduces tramadol consumption and increases analgesia level and patient satisfaction in gynecological operations Keywords: Dexmedetomidine, gynecological operations, patient controlled analgesia, postoperative pain, tramadol
\end{abstract}

Öz

Amaç: $\mathrm{Bu}$ çalışmada Pfannenstiel kesisi yapılan jinekolojik prosedürlerde postoperatif ağrı tedavisinde intravenöz tramadol ile intravenöz tramadole ilave deksmedetomidinin analjezi ve hemodinamik parametrele üzerine etkilerinin karşılaştırılması amaçlanmıştır.

Yöntemler: Genel anestezi altında elektif Pfannenstiel kesisi uygulanarak jinekolojik operasyon planlanan ASA I-II grubuna dahil 60 hasta randomize olarak iki gruba ayrıldı (Grup C (Tramadol grubu) ve Grup D Tramadol + Deksmedetomidin). Operasyon sonrası derlenme odasına alınan her iki gruptaki hastalara ameliyat sonrası 24 saat boyunca hasta kontrollu analjezi (HKA) uygulandı (Grup C için $20 \mathrm{dk}$ kilitli kalma süresi ile $20 \mathrm{mg}$ tramadol bolus doz, Grup D için ilk 4 saat $20 \mathrm{mg}$ tramadol+10mcg deksmedetomidin bolus doz, daha sonra 20 mg tramadol bolus doz). Postoperatif değerlendirmede, sözel ağrı skoru, sedasyon skoru, bulantı ve kusma skoru, tramadol kullanımı ile hemodinamik parametreler ve hasta memnuniyeti kaydedildi.

Bulgular: Postoperatif ağrı skorları Grup D'de, Grup C'ye göre anlamlı olarak düşüktü ve hasta kontrollü analjezi tramadol kullanımı Grup D'de anlamlı olarak azaldı. Toplam PCA tramadol kullanımı Grup D'de Grup C ile karşılaştırıldığında \% 27 azaldı $(p=0,001)$. Ağrı tedavisi ile hasta memnuniyeti Grup D'de Grup C'ye göre anlamlı olarak yükseldi ( $p=0,001)$. Grup D'de 1, 2 ve 4 saatte sedasyon skorlarında anlamlı bir artış gözlendi. Kalp hızı, Grup D'de postoperatif 1,2 ve 4 saatte daha düşüktü (sırası ile $p=0,001, p=0,001$ and $p=0,01$, respectively). Bulantı ve kusma skoru Grup D'de daha düşüktü (hepsi için p<0,05).

Sonuç: Deksmedetomidinin PCA yöntemiyle tramadole eklenmesi, tramadol tüketimini önemli ölçüde azaltmakta ve jinekolojik operasyonlarda analjezi düzeyini ve hasta memnuniyetini artırmaktadır.

Anahtar kelimeler: Deksmedetomidin, jinekolojik ameliyatlar, hasta kontrollü analjezi, postoperative ağrı, tramadol
Department of Anesthesiology and Reanimation, GATA Haydarpaşa Training Hospital, Istanbul, Turkey.

2 Department of Anesthesiology and Reanimation, Sanko University, Faculty of Medicine, Gaziantep, Turkey.

3 Department of Assisted Reproduction, Şişli Kolan International Hospital, Istanbul, Turkey. 4 Department of Obstetrics and Gynecology, University of Health Sciences, Tepecik Training and Research Hospital, Izmir, Turkey.

Ethics Committee Approval: The study was approved by Ministry of Health, Turkish Medicines and Medical Devices Agency, Ethics Advisory Committee (16/31.05.2010).

Etik Kurul Onayı: Çalışma Sağlık Bakanlığı, Türkiye İlaç ve Tıbbi Cihaz Kurumu Etik Kurulu tarafindan onaylanmıştır (16/31.05.2010).

Conflict of Interest: No conflict of interest was declared by the authors.

Çıkar Çatışması: Yazarlar çıkar çatışması bildirmemişlerdir.

Financial Disclosure: The authors declared that this study has received no financial support.

Finansal Destek: Yazarlar bu çalışma için finansal destek almadıklarını beyan etmişlerdir.

Geliş Tarihi / Received: 10.05.2018

Kabul Tarihi / Accepted: 02.07.2018

Yayın Tarihi / Published: 20.07.2018

Sorumlu yazar / Corresponding author:

Bulat Aytek Şık

Şişli Kolan International Hospital,

Department of Assisted Reproduction, Istanbul, Turkey

Phone: 05325966990

E-mail address: bulataytek@gmail.com

Copyright (C) ACEM 


\section{Introduction}

Objectives of the postoperative pain treatment include minimizing or eliminating pain of the patient, facilitating recovery, preventing complications that may occur due to pain and ensuring a cost-effective treatment [1]. An additive, even synergistic analgesic effect may be obtained with the combination of two agents that provide analgesic effect by different mechanisms. Recently, multimodal approaches are studied using the different types of analgesics. Dexmedetomidine is a potent and highly selective $\alpha 2$ receptor agonist. It creates a state of deep sedation at therapeutic doses but does not cause respiratory depression [2]. Dexmedetomidine, when used as premedication, is known to reduce the analgesic requirement during and after surgery. Analgesic requirement is also reduced in patients given sedation with dexmedetomidine at intensive care unit [3].

In our study, we aimed to investigate and compare the effects of intravenous (IV) tramadol and addition of IV dexmedetomidine to tramadol by patient-controlled analgesia (PCA) method on postoperative analgesia, postoperative tramadol consumption, pain score, sedation score, nausea and vomiting, hemodynamic and respiratory parameters and patient satisfaction during early postoperative period in gynecologic procedures.

\section{Materials and methods}

The study was designed as a prospective, randomized controlled trial to be conducted at a public hospital, Department of Anesthesiology and Reanimation, between December 2009 and June 2010. After obtaining ethics approval, 60 patients were included in the study who was aged 18-65 years, categorized in American Society of Anesthesiologists Classification (ASA) risk group I-II, undergoing total abdominal hysterectomy with general anesthesia. The statistical power of a study was $100 \%$ when the average of the 24th hour Visual Analog Scale (VAS) was taken $1.60 \pm 1.0$ for Group C, $0.17 \pm 0.37$ for Group D with $5 \%$ alpha error, also the statistical power of the study was $98.6 \%$ when an average of tramadol was taken $432.00 \pm 146.27$ for Group C and $316.00 \pm 44.06$ for Group D. At the end of the study, it was found that the effect size for the Visual Analog Scale (VAS) in each group with a sample of 30 people was 1.55 and that power was 0.99 .

This trial was approved by the Ministry of Health of Turkey, General Directorate of Pharmaceuticals and Pharmacy, Drug Clinical Research Ethics Advisory Committee-II with a date of 31.05.2010 and decision number of 16. Written informed consent was obtained from all participants. The study was performed according to the Helsinki Declaration.

Exclusion criteria were age below 18 years and above 65 years, advanced heart disorder, kidney disorder, history of epilepsy and convulsion, use of antidepressants, presence of liver disorder, neuropsychiatric disorders, use of antidepressants and beta-adrenoceptor blocking agents, history of allergy to the agents to be used, history of chronic analgesic use, patients who will not be able to comply with patient controlled analgesia (PCA) use, who do not agree to participate in study and who are not cooperative.
60 ASA I-II subjects included in the study were divided into 2 groups according to computerized randomization table during the study as Group C (Control - Tramadol group) (n=30) and Group D (Tramadol + Dexmedetomidine group) $(n=30)$. Both the patients and the observers were blinded with respect to the group allocation. Double-blinding was obtained by labeling the PCA reservoir bags with a specific identification number only. The blinding code retained by the pharmacy was opened after completion of the study. For reasons of patient safety, a sealed envelope containing the treatment assignment was kept with the patient in the post anesthesia care unit (PACU) and general ward. Unblinding would be carried out when an adverse event occurred and this knowledge was required for emergency treatment. Patients developing any complication during and after surgery were planned to be excluded from study. Patients were given detailed information on whole anesthesia procedure, surgical preparations, premedication, transfer to operating room and operations thereof and written consents were obtained. Patients were instructed on use of PCA device (Abbott Pain Manager, Abbott Laboratories, Chicago, IL, USA) and verbal rating scale (VRS), which we used in evaluation of pain.

No premedication was administered to the patients before the surgery. Standard monitoring including systolic, diastolic and mean blood pressures (SBP, DBP, MBP), heart rate (HR) and peripheral oxygen saturation $(\mathrm{SpO} 2)$ by pulse oximetry was applied to the patients transferred to operating room. $20 \mathrm{G}$ intravenous catheter was inserted through a suitable vein at antecubital region and infusion of $0.9 \% \mathrm{NaCl}$ was initiated for the patients.

Induction was started by $2 \mathrm{mg} / \mathrm{kg}$ propofol (Propofol 1 $\%$, Fresenius Kabi, Istanbul, Turkey), fentanyl $2 \mathrm{mcg} / \mathrm{kg}$ (Fentanyl 0,05 mg/ml, Johnson and Johnson, Istanbul, Turkey) and $0.1 \mathrm{mg} / \mathrm{kg}$ vecuronium (Norcuron, Merck Sharp \& Dohme, Istanbul, Turkey) followed by intubation of the patients and anesthesia was maintained by $1-2 \%$ sevoflurane (Sevorane, Abbott, Istanbul, Turkey) in a 50/50\% mixture of O2/N2O with a flow of $6 \mathrm{~L} / \mathrm{min}$. An additional vecuronium bromide of 0.01 $\mathrm{mg} / \mathrm{kg}$ was administered as needed for neuromuscular block. All patients were applied subcutaneous suture and given $1 \mathrm{mg} / \mathrm{kg}$ tramadol $\mathrm{HCl}$ (Contramal, Abdi Ibrahim, Istanbul, Turkey) by intravenous route. At the end of the surgery, residual neuromuscular block was antagonised by $0.06 \mathrm{mg} / \mathrm{kg}$ neostigmine methylsulphate (Neostigmine, Adeka, Samsun, Turkey) and $0.02 \mathrm{mg} / \mathrm{kg}$ atropine sulphate (Atropine Sulphate, Biofarma, Istanbul, Turkey). Patients were extubated according to extubation criteria.

Patients were awakened at the end of surgery and taken into the recovery room where they were given oxygen at a rate of 3-5 L/min by a face mask. Patients in Group C (Tramadol group) were given $2 \mathrm{mg} / \mathrm{ml}$ tramadol $\mathrm{HCl}$ (Contramal, Abdi Ibrahim, Istanbul, Turkey) in $100 \mathrm{~mL} 0.9 \% \mathrm{NaCl}$ by PCA device for 24 hours with a bolus dose of $20 \mathrm{mg}$, lockout time of 15 minutes and a 4-hour limit dose of $200 \mathrm{mg}$ and no basal infusion was administered.

Patients in Group D were given $2 \mathrm{mg} / \mathrm{mL}$ tramadol $\mathrm{HCl}$ (Contramal, Abdi Ibrahim, Istanbul, Turkey) in $100 \mathrm{~mL} 0.9 \%$ $\mathrm{NaCl}$ and $1 \mathrm{mcg} / \mathrm{mL}$ dexmedetomidine (Precedex, Abbott, Istanbul, Turkey) by PCA pump at the recovery room for the first 
4 hours postoperatively with a lockout time of 15 minutes and a bolus dose of $20 \mathrm{mg}$ tramadol $\mathrm{HCl}+10 \mathrm{mcg}$ dexmedetomidine and no basal infusion was administered. Afterwards, treatment of patients was continued with $2 \mathrm{mg} / \mathrm{ml}$ tramadol $\mathrm{HCl}$ (Contramal, Abdi Ibrahim, Istanbul, Turkey) in $100 \mathrm{~mL} 0.9 \% \mathrm{NaCl}$ by PCA pump with a bolus dose of $20 \mathrm{mg}$, lockout time of 15 minutes and a 4-hour limit dose of $200 \mathrm{mg}$ until 24 hours postoperatively. During follow-up, a VRS score of $>4$ was considered to be insufficient analgesia and; thus, $0.5 \mathrm{mg} / \mathrm{kg}$ intramuscular meperidine (Aldolan $100 \mathrm{mg}$, Liba, Istanbul, Turkey) was administered as rescue analgesia and the time of administration was recorded.

Patients were visited at the $1 \mathrm{st}, 2 \mathrm{nd}, 4 \mathrm{th}, 8 \mathrm{th}, 12 \mathrm{th}, 16 \mathrm{th}$, 20th and 24th hours postoperatively and monitored for HR, SBP, DBP, MBP, SpO2, respiratory rate, VRS (pain score at rest and with coughing), sedation score, total amount of dexmedetomidine intake, additional analgesic need, demanded vs. total consumed tramadol amount and side effects (nausea, vomiting, itching, sedation, hypotension, bradycardia, respiratory depression, dizziness, headache) and the results were recorded. There was no lost data because all data is recorded by researchers.

Patients' satisfaction with their postoperative pain management was assessed using a 10-point VRS, with $1=$ highly dissatisfied to $10=$ completely satisfied. Assessment of postdischarge pain was performed using a 10 -point VRS, with $0=$ no pain and 10=worst pain imaginable. All measurements were recorded by a research assistant who was blinded to the study medication. Sedation score was evaluated by a 4-point scale ( 0 =awake; $1=$ sleepy; $2=$ arousable; $3=$ deep sleep). Nausea and vomiting was evaluated by a 3 -point scale $(0=$ no nausea; $1=$ only nausea, no vomiting; $2=$ nausea with vomiting).

A HR below 50 beat $/ \mathrm{min}$ was considered as bradycardia and a respiratory rate of $\leq 8$ and $\mathrm{SpO} 2$ below $90 \%$ were considered as respiratory depression. It was planned to administer $0.5 \mathrm{mg}$ IV atropine (Atropine Sulphate, Biofarma, Istanbul, Turkey) for bradycardia and respiratory and oxygen support for respiratory depression which was to be followed by naloxone (Nalokson HCI, Abbott, Istanbul, Turkey) (0.1 mg every 2-3 minutes until the response is achieved) in case of absence of response. A reduction of $>30 \%$ in MBP from baseline or a SBP below $90 \mathrm{mmHg}$ was considered as hypotension and it was planned to administer a rapid infusion of $500 \mathrm{~mL}$ crystalloid followed by $5 \mathrm{mg}$ IV ephedrine (Ephedrine, Osel, Istanbul, Turkey) in case of absence of response. $4 \mathrm{mg}$ IV ondansetron (Zofran, Glaxo Smith Kline, Istanbul, Turkey) was planned to be administered to subjects with a nausea-vomiting score of $2.1 \mathrm{mg}$ IV pheniramine maleate (Avil, Sandoz, Istanbul, Turkey) was planned to be administered in case of itching.

\section{Statistical Analysis}

Data were collected after that transferred into the computer. Statistical Package for Social Sciences (SPSS) for Windows 15.0 program was used for statistical analyses when evaluating the study findings. The descriptive statistics for categorical variables are presented as counts and percentages and for continuous variables they are presented as averages, standard deviations, medians, 25 and 75 percentiles with minimum and maximum. For continuous variables Kolmogorov-Smirnov test is used for testing differences between groups when the assumption of normality is not satisfied. Independent samples t-test was used to compare continuous data in two independent groups that fit normal distribution, while Mann Whitney U-test was used in non-parametric tests in non-normal distributions. Fischer's Exact test was used in comparison of discrete data. A p value of $<0.05$ was considered to be statistically significant.

\section{Results}

No statistically significant difference was detected between the study groups with respect to age, body weight, height, ASA and duration of anesthesia (Table 1). Comparison of mean arterial pressures between the study groups showed no statistically significant difference ( $p>0.05$ for all). Heart rates were statistically significantly lower in Group D compared to Group C at 1st, 2nd and 4th hours (p=0.001, p=0.001 and $\mathrm{p}=0.01$, respectively) (Table 2 ).

\begin{tabular}{|c|c|c|c|}
\hline & $\begin{array}{c}\text { Group } C(\mathrm{n}=30) \\
\text { Mean } \pm \mathrm{SD}\end{array}$ & $\begin{array}{c}\text { Group } \mathrm{D}(\mathrm{n}=30) \\
\text { Mean } \pm \text { SD }\end{array}$ & $\mathrm{p}^{*}$ \\
\hline Age (years) & $45.93 \pm 9.01$ & $47.20 \pm 6.20$ & 0.53 \\
\hline Body weight $(\mathrm{kg})$ & $69.73 \pm 11.70$ & $67.40 \pm 12.17$ & 0.45 \\
\hline Height $(\mathrm{cm})$ & $163.10 \pm 4.26$ & $162.96 \pm 4.82$ & 0.91 \\
\hline $\begin{array}{l}\text { Duration of } \\
\text { anesthesia (min) }\end{array}$ & $75.13 \pm 18.02$ & $69.86 \pm 20.57$ & 0.29 \\
\hline ASA (I/II) & $30 / 9$ & $30 / 4$ & 0.52 \\
\hline
\end{tabular}

ASA: American Society of Anesthesiologists Classification

Table 2: Postoperative hemodynamic parameters of groups (MBP, HR).

\begin{tabular}{lccc}
\hline & Group C $(\mathrm{n}=30)$ & Group D $(\mathrm{n}=30)$ & $\mathrm{p}$ \\
\hline MBP (1 h) & $89.33 \pm 12.51$ & $86.603 \pm 10.72$ & 0.36 \\
MBP (2 h) & $87.77 \pm 7.80$ & $86.03 \pm 11.05$ & 0.48 \\
MBP (4 h) & $84.87 \pm 19.73$ & $84.50 \pm 7.45$ & 0.92 \\
MBP (8 h) & $85.20 \pm 8.40$ & $88.70 \pm 3.23$ & 0.06 \\
MBP (12 h) & $84.13 \pm 9.40$ & $81.97 \pm 5.73$ & 0.28 \\
MBP (16 h) & $82.67 \pm 9.25$ & $84.90 \pm 10.78$ & 0.39 \\
MBP (20 h) & $84.37 \pm 10.41$ & $83.63 \pm 8.39$ & 0.76 \\
MBP (24 h) & $83.30 \pm 10.31$ & $82.37 \pm 7.50$ & 0.69 \\
HR (1 h) & $77.53 \pm 10.47$ & $66.53 \pm 11.05$ & $<0.001$ \\
HR (2 h) & $77.17 \pm 8.28$ & $66.80 \pm 11.32$ & $<0.001$ \\
HR (4 h) & $78.73 \pm 10.78$ & $67.43 \pm 14.18$ & 0.01 \\
HR (8 h) & $74.33 \pm 5.92$ & $70.70 \pm 11.09$ & 0.12 \\
HR (12 h) & $73.90 \pm 6.70$ & $71.97 \pm 10.74$ & 0.41 \\
HR (16 h) & $73.57 \pm 7.89$ & $69.87 \pm 9.63$ & 0.10 \\
HR (20 h) & $72.20 \pm 6.47$ & $68.97 \pm 6.42$ & 0.06 \\
HR (24 h) & $71.27 \pm 5.42$ & $68.97 \pm 5.46$ & 0.11 \\
\hline
\end{tabular}

Scores for pain at rest (VRSr) were statistically significantly lower in Group D compared to Group C at all postoperative time points $(\mathrm{p}=0.001)$ (Table 3$)$. Scores for pain with coughing (VRSc) were statistically significantly lower in Group D compared to Group C at all postoperative time points $(\mathrm{p}=0.001)$ (Table 3). Postoperative hourly tramadol consumption of the patients by PCA device were statistically significantly lower in Group D compared to Group C at 12th, 16th, 20th and 24th hours postoperatively ( $\mathrm{p}=0.001$ for all) (Table 4). Total tramadol consumption was also lower in Group D compared to Group C ( $\mathrm{p}=0.001) \quad$ (Table 4). The hourly and total dexmedetomidine consumption used by Group D was also calculated. Total dexmedetomidine consumption was $79.7 \pm 11.3$ mcg in first 4 hours (Table 5). 
Table 3: VRSr values of the groups (at the rest and with coughing).

\begin{tabular}{clccccc}
\hline VRSr & \multicolumn{3}{c}{ Rest } & \multicolumn{3}{c}{ With coughing } \\
\cline { 2 - 7 } & $\begin{array}{l}\text { Group C } \\
(\mathrm{n}=30)\end{array}$ & $\begin{array}{c}\text { Group D } \\
(\mathrm{n}=30)\end{array}$ & $\mathrm{p}$ & $\begin{array}{c}\text { Group C } \\
(\mathrm{n}=30)\end{array}$ & $\begin{array}{c}\text { Group D } \\
(\mathrm{n}=30)\end{array}$ & $\mathrm{p}$ \\
\hline $1 \mathrm{~h}$ & $4.43 \pm 2.70$ & $2.60 \pm 1.13$ & $<0.001$ & $6.67 \pm 2.29$ & $4.23 \pm 0.97$ & $<0.001$ \\
$2 \mathrm{~h}$ & $4.33 \pm 1.95$ & $2.07 \pm 0.78$ & $<0.001$ & $6.40 \pm 1.94$ & $3.50 \pm 0.73$ & $<0.001$ \\
$4 \mathrm{~h}$ & $4.47 \pm 5.56$ & $1.40 \pm 1.03$ & $<0.001$ & $5.63 \pm 1.67$ & $2.77 \pm 1.35$ & $<0.001$ \\
$8 \mathrm{~h}$ & $2.93 \pm 1.25$ & $1.37 \pm 1.06$ & $<0.001$ & $5.03 \pm 1.84$ & $3.27 \pm 1.63$ & $<0.001$ \\
$12 \mathrm{~h}$ & $2.50 \pm 1.07$ & $0.90 \pm 1.06$ & $<0.001$ & $4.37 \pm 1.77$ & $2.77 \pm 0.97$ & $<0.001$ \\
$16 \mathrm{~h}$ & $2.20 \pm 1.32$ & $0.63 \pm 0.61$ & $<0.001$ & $3.80 \pm 1.60$ & $2.20 \pm 0.96$ & $<0.001$ \\
$20 \mathrm{~h}$ & $2.13 \pm 1.16$ & $0.50 \pm 0.63$ & $<0.001$ & $3.40 \pm 1.47$ & $1.83 \pm 0.98$ & $<0.001$ \\
$24 \mathrm{~h}$ & $1.60 \pm 1.03$ & $0.17 \pm 0.37$ & $<0.001$ & $2.77 \pm 1.35$ & $1.30 \pm 1.11$ & $<0.001$ \\
\hline VRS: verbal rating scale & & & & &
\end{tabular}

Number of postoperative analgesic demands of the patients by PCA device were statistically significantly lower in Group D compared to Group C at all follow-up time points ( $p<0.05$ for all). Comparison of the study groups showed that the number of patients with an additional analgesic need postoperatively was statistically lower in Group D with six patients (20\%) compared to Group C with 14 patients (46.7\%), and the patient satisfaction was significantly higher in Group D $(9.23 \pm 0.72)$ compared to Group $\mathrm{C}(8.20 \pm 0.84) \quad(\mathrm{p}=0.04$ and $\mathrm{p}=0.001$, respectively).

Table 4: Comparision of hourly and 24 hours total tramadol consumption of groups (mg).

\begin{tabular}{lccc}
\hline $\begin{array}{l}\text { Hourly Tramadol } \\
\text { consumption }(\mathrm{mg})\end{array}$ & $\begin{array}{c}\text { Group C } \\
(\mathrm{n}=30)\end{array}$ & $\begin{array}{c}\text { Group D } \\
(\mathrm{n}=30)\end{array}$ & $\mathrm{p}$ \\
\hline $1 \mathrm{~h}$ & $56.00 \pm 19.93$ & $60.66 \pm 16.17$ & 0.32 \\
$2 \mathrm{~h}$ & $50.00 \pm 23.34$ & $42.66 \pm 11.42$ & 0.12 \\
$4 \mathrm{~h}$ & $60.66 \pm 19.98$ & $56.00 \pm 15.22$ & 0.31 \\
$8 \mathrm{~h}$ & $67.33 \pm 37.31$ & $52.66 \pm 23.77$ & 0.07 \\
$12 \mathrm{~h}$ & $70.00 \pm 35.13$ & $42.66 \pm 20.16$ & $<0.001$ \\
$16 \mathrm{~h}$ & $52.66 \pm 30.39$ & $28.66 \pm 18.70$ & $<0.001$ \\
$20 \mathrm{~h}$ & $44.66 \pm 35.88$ & $20.66 \pm 12.29$ & $<0.001$ \\
$24 \mathrm{~h}$ & $30.66 \pm 23.91$ & $12.00 \pm 9.96$ & $<0.001$ \\
\hline 24 hours total & $432.00 \pm 146.27$ & $316.00 \pm 44.06$ & $<0.001$ \\
\hline
\end{tabular}

Table 5: Hourly Dexmedetomidin consumption by PCA device (mcg).

\begin{tabular}{lll}
\hline $\begin{array}{l}\text { Hourly Dexmedetomidine } \\
\text { consumption (mcg) }\end{array}$ & Mean \pm SD & Range \\
\hline $1 \mathrm{~h}$ & $30.33 \pm 8.08$ & $0-40$ \\
$2 \mathrm{~h}$ & $21.33 \pm 5.71$ & $10-30$ \\
$4 \mathrm{~h}$ & $28.00 \pm 7.61$ & $10-40$ \\
\hline Total & $79.66 \pm 11.29$ & $40-100$ \\
\hline
\end{tabular}

Comparison of side effects revealed no instances of bradycardia, hypotension, dry mouth, itching and respiratory depression in the patients. Comparison of nausea and vomiting scores of groups showed statistically significantly lower scores for Group D compared to Group C ( $p<0.05$ for all) (Table 6). Sedation score was found to be statistically significantly high at 1st, 2nd and 4th hours in Group D ( $\mathrm{p}<0.05$ for all).

Table 6: Nausea-vomiting scores of the groups.

\begin{tabular}{lccc}
\hline Nausea & $\begin{array}{c}\text { Group C } \\
(\mathrm{n}=30)\end{array}$ & $\begin{array}{c}\text { Group D } \\
(\mathrm{n}=30)\end{array}$ & $\mathrm{p}$ \\
Vomiting & $\mathrm{n}(\%)$ & $\mathrm{n}(\%)$ & \\
\hline 0 & $10(33.3)$ & $20(66.7)$ & 0.03 \\
1 & $17(56.7)$ & $9(30)$ & 0.03 \\
2 & $3(10)$ & $1(3.3)$ & 0.01 \\
\hline
\end{tabular}

\section{Discussion}

Our study demonstrated that the combination of dexmedetomidine and tramadol administered by PCA for the first 4 hours postoperatively minimized the analgesic consumption for the first 24 hours postoperatively, reduced opioid-related nausea-vomiting and increased the patient satisfaction in gynecologic procedures with Pfannenstiel incision. In addition, no cases of severe bradycardia, oversedation and respiratory depression were observed.

Many studies conducted during the postoperative period reported that tramadol induces less respiratory depression, less sedation and fewer effects on intestinal motility than potent opioids [4]. Dexmedetomidine is a potent selective alpha-2 agonist that has sedative, analgesic and anxiolytic properties [5]. Alpha-2 agonists and especially dexmedetomidine have come into prominence for postoperative pain management in many reports published in recent years [6, 7], and become an attractive treatment option in multimodal pain management [8, 9]. Dexmedetomidine was observed to have a widespread coverage in anesthesia literatures because of its desired properties in perioperative and postoperative periods $[7,10,11]$.

Hemodynamic changes developed following the administration of dexmedetomidine are complex. Following the loading dose, a transient hypertension develops with subsequent hypotension and bradycardia because of its direct vasoconstrictive effect [7, 12]. Use of an agent with such direct cardiovascular effects as part of the postoperative analgesia regimen may give rise to concerns about the occurrence of potentially harmful hemodynamic effects. Icrkering et al. [13] have demonstrated that the infusion without a loading dose leads to a reduction in undesirable hemodynamic effects. Therefore, we preferred to use PCA device only for postoperative pain management in our study. Omission of intraoperative loading dose of dexmedetomidine reduced the suspicions about the potential negative chronotropic effects. A meta-analysis by Wang Guoqi et al. [14] reported that dexmedetomidine reduces the arterial blood pressure and heart rate. Likewise, Cormack et al. [15] emphasized that dexmedetomidine has complications such as hypotension and bradycardia but these are dependent on the dose and can easily be treated. We found no statistically significant difference in MBP in comparison of our study groups. Heart rate values were found to be statistically lower in dexmedetomidine + tramadol HCL group at the 1st, 2nd and 4th hours. We believe that this result is related to the effect of dexmedetomidine, in consistent with the results of other studies. No bradycardia case was observed clinically in our patients. We attributed this to the use of low dose dexmedetomidine.

Cortinez et al. [16] have demonstrated the analgesic efficacy of dexmedetomidine in humans by target controlled infusion of intravenous dexmedetomidine (equal to $0.5 \mathrm{mcg} / \mathrm{kg}$ concentration) which results in a blood concentration of 0.6 $\mathrm{ng} / \mathrm{mL}$. Recent studies showed that intraoperative dexmedetomidine use (bolus dose of $0.5-1 \mu \mathrm{g} / \mathrm{kg}$, with or without continuous infusion of $0.5-2 \mu \mathrm{g} / \mathrm{kg}$ per hour) leads to an important reduction in intraoperative and postoperative analgesic need. $[17,18]$. In one study, authors reported that intraoperative 
dexmedetomidine use does not only reduce the postoperative analgesic requirements but also intraoperative anesthetic need [19].

Cold compression test was performed in subjects following the administration of dexmedetomidine or clonidine in several experimental studies conducted with volunteers. These studies showed that the VRS pain scores are reduced by 20 to $30 \%$ in individuals in state of moderate to deep sedation depending on the various doses of these agents [20, 21]. Improved analgesia by dexmedetomidine might come from the synergistic analgesic interactions with opioids, reduction of stress, and attenuation on the affective-motivational component (unpleasantness) of pain. Also in our study, postoperative VRS pain scores and sedation evaluations between groups demonstrated that the VRS pain scores were significantly lower in dexmedetomidine group at all time-points. Sedation score was found to be statistically significantly high at the 1st, 2nd and 4th hours. Because the mean VRS pain scores were below 5 at all time-points in dexmedetomidine group, we concluded that the addition of dexmedetomidine leads to a more rapid and effective analgesia. In addition, based on the mean sedation scores of $0-1$, we believe that the patients can be more cooperative and relaxed during the postoperative care. We also believe that the sedative efficacy obtained at the recovery room and after surgery by the addition of dexmedetomidine to tramadol may contribute to the low levels of pain in patients. Furthermore, because of the sedated state of patients, tramadol HCL use by PCA device, which is based on the patient's direct participation to the therapy, may have been reduced.

Arain et al. [22] demonstrated that the administration of $1 \mathrm{mcg} / \mathrm{kg}$ dexmedetomidine injection within 10 minutes before termination of surgery followed by $0.4 \mathrm{mcg} / \mathrm{kg} / \mathrm{hour}$ dexmedetomidine infusion for 4 hours better reduced the postoperative morphine use when compared to $0.08 \mathrm{mg} / \mathrm{kg}$ morphine injection. Likewise, Lin et al. [23] compared morphine only and dexmedetomidine + morphine groups using PCA for postoperative analgesia in total hysterectomy procedures and found a significantly lower analgesic need in dexmedetomidine + morphine group. In addition, single dose of dexmedetomidine given prior to induction reduced the postoperative morphine use by PCA device [24]. Our study found that tramadol dose used postoperatively was lower in the group given combination of dexmedetomidine-tramadol when compared to group given tramadol only for 24 hours. Tramadol need was $27 \%$ lower in the group given dexmedetomidine. Number of analgesic demands by PCA device was also significantly lower in dexmedetomidinetramadol group.

Venn et al. [25] investigated the effects of dexmedetomidine in postoperative setting in a study conducted in 119 cardiac surgery and general surgery patients who were in need of mechanic ventilation intensive care and sedation. They found that dexmedetomidine reduced the need for emergency sedation and exhibited a depot analgesic effect. Elimination halflife of dexmedetomidine is approximately 2-3 hours and the authors suggest that its depot analgesic effect is prolonged up to 24 hours. In support of these results, we also observed that the VRS pain scores in first 24 hours postoperatively were lower than those of control group at all time-points with a significant reduction in tramadol requirement and a significant reduction in additional analgesic need in dexmedetomidine group. This prolonged postoperative analgesic effect of dexmedetomidine can be explained by the effects of alpha- 2 agonists on emotional component of the postoperative pain owing to their anxiolytic and thymoanaleptic effects [26].

No patient developed respiratory depression (respiratory rate $<10)$ or desaturation episode $\left(\mathrm{SpO}_{2}<90\right)$ during the postoperative follow-up. Previous studies have demonstrated that dexmedetomidine does not cause respiratory depression despite the deep sedation levels achieved with it. It was determined that alpha-2 adrenoceptors do not play an active role in respiratory center [27].

Dexmedetomidine reduces the noradrenergic activity by its effect on presynaptic alpha-2 receptors, and this may be responsible for its antiemetic effect [28]. Sedative effect of dexmedetomidine on locus coeruleus exerted through adrenoceptors may also contribute to its antiemetic effect. In our study, addition of dexmedetomidine to tramadol resulted in a lower incidence of nausea and vomiting and reduced metoclopramide need at recovery room. This may be associated with the reduced use of tramadol, which causes nausea, ensured by dexmedetomidine as well as the alpha- 2 agonist effect of dexmedetomidine that relieve nausea [29, 30]. Dexmedetomidine use by PCA device can be a reasonable strategy in coping with postoperative nausea and vomiting especially in patients with a history of treatment-resistant nausea [27]. Based on these, patient satisfaction was found to be higher in dexmedetomidine group in our study.

Limitations of the study are the number of patient groups in the study. Also patients' postoperative analgesic needs, patient comfort and satisfaction could be assessed longer time and postoperative Tramadol + Dexmedetomidine administration could be longer than 24 hours.

In conclusion, the combination of tramadoldexmedetomidine reduces the postoperative analgesic use in patient-controlled analgesia when compared to tramadol alone. In addition, combination of tramadol-dexmedetomidine leads to a reduction in frequency of nausea and vomiting as well as antiemetic use and does not impact respiratory parameters. Postoperative use of dexmedetomidine might create hesitation due to sedation side effects, but we did not find such an effect in our work. We thought that the most important reason was the use of PCA set at the appropriate dose.

Based on these findings, we believe that the addition of dexmedetomidine, which exerts sedative, analgesic and anxiolytic effects, to tramadol by intravenous route will provide an effective analgesia and a more comfortable postoperative care for the patients.

\section{References}

1. Saygı Aİ, Özdamar Ö, Gün İ, Emirkadı H, Müngen E, Akpak YK Comparison of maternal and fetal outcomes among patients undergoing cesarean section under general andspinal anesthesia: a randomized clinical trial. Sao Paulo Med J. 2015;133:227-34.

2. Schnabel A, Meyer-Frießem CH, Reichl SU, Zahn PK, Pogatzki-Zahn EM. Is intraoperative dexmedetomidine a new option for postoperative pain treatment? A meta-analysis of randomized controlled trials. Pain. 2013;154:1140-9. 
3. Cruickshank M, Henderson L, MacLennan G, Fraser C, Campbell M, Blackwood B, et al. Alpha-2 agonists for sedation of mechanically ventilated adults in intensive care units: a systematic review. Health Technol Assess. 2016; 20:v-xx, 1-117.

4. Falzone E1, Hoffmann C, Keita H. Postoperative analgesia in elderly patients. Drugs Aging. 2013;30:81-90.

5. Ebert TJ, Hall JE, Barney JA, Uhrich TD, Colinco MD. The effects of increasing plasma concentrations of dexmedetomidine in humans. Anesthesiology. 2000;93:382-94.

6. Fairbanks CA, Kitto KF, Nguyen HO, Stone LS, Wilcox GL. Clonidine and dexmedetomidine produce antinociceptive synergy in mouse spinal cord. Anesthesiology. 2009;110:638-47.

7. Gil DW, Cheevers CV, Kedzie KM, Kedzie KM, Manlapaz CA, Rao S, et al. Alpha-1-adrenergic receptor agonist activity of clinical alphaadrenergic receptor agonists interferes with alpha-2-mediated analgesia. Anesthesiology. 2009;110:401-17.

8. Grosu I, Lavand'homme P. Use of dexmedetomidine for pain control. F1000 Med Rep. 2010;2:90.

9. Blaudszun G, Lysakowski C, Elia N, Tramer MR. Effect of perioperative systemic alpha2 agonists on postoperative morphine consumption and pain intensity: systematic review and meta-analysis of randomized controlled trials. Anesthesiology. 2012;116:1312-22.

10. Nelson S, Muzyk AJ, Bucklin MH, Brudney S, Gagliardi JP. Defining the Role of Dexmedetomidine in the Prevention of Delirium in the Intensive Care Unit.Biomed Res Int. 2015;2015:635737.

11. Peng K, Jin XH, Liu SL, Ji FH. Effect of Intraoperative Dexmedetomidine on Post-Craniotomy Pain. Clin Ther. 2015;37:111421.

12. Zhang X, Wang R, Lu J, Jin W, Qian Y, Huang P, et al. Effects of different doses of dexmedetomidine on heart rate and blood pressure in intensive care unit patients. Exp Ther Med. 2016;11:360-6.

13. Ickeringill M, Shehabi $\mathrm{Y}$, Adamson $\mathrm{H}$, Ruettimann $\mathrm{U}$. Dexmedetomidine infusion without loading dose in surgical patients requiring mechanical ventilation: hemodynamic effects and efficacy. Anaesth Intensive Care 2004;32:741-5.

14. Wang G, Zhang L, Lou S, Chen Y, Cao Y, Wang R, et al. Effect of Dexmedetomidine in Preventing Postoperative Side Effects for Laparoscopic Surgery: A Meta-Analysis of Randomized Controlled Trials and Trial Sequential Analysis (PRISMA). Medicine (Baltimore). 2016;95:e2927.

15. Cormack JR, Orme RM, Costello TG, The role of alpha-2-agonists in neurosurgery. J Clin Neurosci. 2005;12:375-8.

16. Cortinez LI, Hsu YW, Sum-Ping ST, Young C, Keifer JC, Macleod D. Dexmedetomidine pharmacodynamics: Part II: Crossover comparison of the analgesic effect of dexmedetomidine and remifentanil in healthy volunteers. Anesthesiology. 2004;101:1077-83.

17. Massad IM, Mohsen WA, Basha AS, Al-Zaben KR, Al-Mustafa MM, Alghanem SM. A balanced anesthesia with dexmedetomidine decreases postoperative nausea and vomiting after laparoscopic surgery. Saudi Med J. 2009;30:1537-41.

18. Al-Zaben KR, Qudaisat IY, Al-Ghanem SM, Massad IM, Al-Mustafa MM, Al-Oweidi AS, et al. Intraoperative administration of dexmedetomidine reduces the analgesic requirements for children undergoing hypospadius surgery. Eur J Anaesthesiol. 2010;27:247-52.

19. Gandhi KA, Panda NB, Vellaichamy A, Mathew PJ, Sahni N, Batra YK. Intraoperative and Postoperative Administration of Dexmedetomidine Reduces Anesthetic and PostoperativeAnalgesic Requirements in Patients Undergoing Cervical Spine Surgeries. J Neurosurg Anesthesiol. 2016 Mar 31. [Epub ahead of print]

20. Hall JE, Uhrich TD, Barney JA, Arain SR, Ebert TJ. Sedative, amnestic, and analgesic properties of small-dose dexmedetomidine infusions. Anesth Analg. 2000;90:699-705.

21. Hall JE, Uhrich TD, Ebert TJ. Sedative, analgesic and cognitive effects of clonidine infusions in humans. Br J Anaesth. 2001;86:5-11.

22. Arain SR, Ruehlow RM, Uhrich TD, Ebert TJ. The efficacy of dexmedetomidine versus morphine for postoperative analgesia after major inpatient surgery. Anesth Analg. 2004;98:153-8.
23. Lin TF, Yeh YC, Lin FS, Wang YP, Lin CJ, Sun WZ, et al. Effect of combining dexmedetomidine and morphine for intravenous patientcontrolled analgesia. Br J Anaesth. 2009;102:117-22.

24. Unlugenc H, Gunduz M, Guler T, Yagmur O, Isik G. The effect of preanaesthetic administration of intravenous dexmedetomidine on postoperative pain in patients receiving patient-controlled morphine. Eur J Anaesthesiol. 2005;22:386-91.

25. Venn RM, Bradshaw CJ, Spencer R, Brealey D, Caudwell E, Naughton C. Preliminary UK experience of dexmedetomidine, a novel agent for postoperative sedation in the intensive care unit, Anaesthesia. 1999;54:1136-42.

26. De Kock MF, Pichon G, Scholtes JL. Intraoperative clonidine enhances postoperative morphine patient-controlled analgesia. Can J Anaesth 1992;39:537-44.

27. Arain SR, Ebert TJ. The efficacy, side effects, and recovery characteristics of dexmedetomidine versus propofol when used for intraoperative sedation. Anesth Analg. 2002;95:461-6.

28. Whittington RA, Virág L. Dexmedetomidine-induced decreases in accumbal dopamine in the rat are partly mediated via the locus ceruleus. Anesth Analg. 2006;102:448-55.

29. Abdelmageed WM, Elquesny KM, Shabana RI, Abushama HM, Nassar AM. Analgesic properties of a dexmedetomidine infusion after uvulopalatopharyngoplasty in patients with obstructive sleep apnea. Saudi J Anaesth. 2011; 5: 150-6.

30. Goksu S, Arik H, Demiryurek S, Mumbuc S, Oner U, Demiryurek AT. Effects of dexmedetomidine infusion in patients undergoing functional endoscopic sinus surgery under local anaesthesia. Eur J Anaesthesiol. 2008;25:22-8. 